
Lois Denissa

Komparasi Ruang Fisik Gereja St. Mary Singapore dan Ruang Maya Gereja Injili Indonesia Setrasari

\title{
KOMPARASI RUANG FISIK GEREJA ST. MARY SINGAPORE DAN RUANG MAYA GEREJA INJILI INDONESIA SETRASARI
}

\author{
Lois Denissa \\ (Email: lois_denissa@yahoo.co.id) \\ Program Studi D-III Seni Rupa dan Desain \\ Fakultas Seni Rupa dan Desain \\ Universitas Kristen Maranatha \\ Jl. Prof.drg. Suria Sumantri, MPH no. 65, Bandung, Indonesia
}

\begin{abstract}
ABSTRAK
Gereja sebagai bangunan ibadah dirancang sedemikan rupa mampu memenuhi tugasnya sebagai sebuah bangunan, syarat teknik, dan bentuk. Bentuk sebagai objek yang terlihat secara fisik dirancang dan digunakan untuk memaknai banyak hal. Bentuk selanjutnya tampil sebagai teks atau tanda yang merelasikan bentuk dengan makna. Ruang sekaligus bentuk sebagai kesatuan adalah representasi dari pesan yang disampaikan kepada publik. Gereja St. Mary Of The Angel dirancang sarat dengan tanda bermakna religiusitas, baik sebagai ikon, indeks maupun simbol mulai dari perancangan ruang tapak hingga detail interiornya. Sebaliknya tanda visual yang ada pada Gereja Injili Indonesia Setrasari tidak banyak ditampilkan bahkan dari lokasinya yang berada di mall lantai 2 dengan Giant Supermarket di lantai 1 sangatlah bertolak belakang. Penelitian ini dilakukan untuk melihat relasi tanda objek pada bangunan ibadah yang fisikal nyata dan makna yang direpresentasikannya dengan bangunan ibadah lain dengan makna lahir dari tanda bersifat non fisik atau faktual. Metode dalam penelitian ini menggunakan metode kualitatif komparatif pada tahap kajian dan metode semiotika etnografi pada tahap analisis yaitu melalui pola laku dan wawancara mendalam. Tanda fisik pada Gereja St. Mary Of The Angel dapat terbaca mulai dari ruang pencapaian tapak hingga bentuk detail interiornya. Sebaliknya tanda visual yang ada pada Gereja Injili Indonesia Setrasari tidak banyak ditampilkan bahkan lokasinya berada di Setrasari Mall lantai dua dengan Giant Supermarket di lantai satu sangatlah tidak relevan. Mulai dari ruang pencapaian tapak hingga bentuk detail interior tidak banyak menjelaskan relasi ruang, bentuk, dan makna. Ketidakhadiran tanda visual simbolis bukan berarti hilangnya representasi makna. Nilai religiusitas lahir dalam ruang maya, dipaparkan lebih melalui audio visual seperti penyampaian kotbah, pujian jemaat, paduan suara, presentasi power point, presentasi panel, video klip, drama musikal yang sifatnya life show dari pada tanda visual bentuk dan ruang yang fisikal.
\end{abstract}

Kata kunci: makna; ruang fisik; ruang maya; tanda visual 


\begin{abstract}
The church as a worship building is designed in such a way as to be able to fulfill its duties as a building, technical requirements, and forms. Shapes as objects that are seen physically are designed and used to make sense of many things. The next form appears as a text or sign that relates the shape to the meaning. Space as well as form as a whole is a representation of the message conveyed to the public. The Church of St. Mary of the Angel was designed with meaningful signs of religiosity, both as icons, indexes, and symbols starting from the design of the site space to the interior details. On the other hand, the visual signs on the Indonesian Evangelical Church of Setrasari are not shown much, even from its location on the 2nd floor Giant Supermarket on the 1st floor very opposite. This research is important to do to see the relation of object markings in real physical worship buildings and the meaning they represent with other worship buildings with meanings born of non-physical or factual signs. The method in this study uses a comparative qualitative method at the study stage and ethnographic semiotics method at the analysis stage, namely through behavior patterns and in-depth interviews. Physical markings on the Church of St. Mary of the Angel can be read from the site's achievement space to its interior detail. On the other hand, the visual signs on the Indonesian Evangelical Church of Setrasari are not shown much, even its location on the second floor of Setrasari Mall with Giant Supermarket on the first floor is highly irrelevant. Starting from the space of achievement of the site to the form of interior detail does not explain much the relationship of space, form, and meaning. The absence of visual symbolic signs does not mean loss of meaning representation. The value of religiosity was born in cyberspace, presented more through audiovisuals such as the delivery of sermons, congregational praise, choirs, PowerPoint presentations, panel presentations, video clips, musical plays that are live shows rather than visual signs of physical form and space.
\end{abstract}

Keywords: meaning; physical space; virtual space; visual sign

\title{
PENDAHULUAN
}

Sebuah lingkungan binaan termasuk di dalamnya bangunan arsitektur peribadahan adalah suatu produk budaya yang didukung oleh masyakatnya. Melalui bentukan fisik arsitektur yang kasat mata di dalamnya tercermin pula tata hidup, tata laku, nilai-nilai keyakinan dan nilai idealisme yang tidak kasat mata namun dapat dibaca dan dikenali dari tanda pengorganisasian elemen-elemen fisiknya/teks. Pada bangunan gereja St. Mary of The Angel, Singapore elemen-elemen fisik itu dapat ditemukan dari sejak pencapaian lokasi tapak/main entrance sampai tata letak bangunan dan elemen-elemen pendukung lainnya yang dirancang mengikuti kode tertentu. Elemen-elemen pendukung lain itu antara lain: ruang terbuka, kolam, tiang bendera, jalan setapak/footpath, penataan taman, furnitur, elemen estetik eksterior maupun interiornya.

Bangunan utama adalah bangunan gereja, terletak di penghujung tapak yang memanjang memiliki pintu masuk utama menghadap ruang terbuka yang luas/ Entry Court, dengan kolam di tengah-tengah, jalan setapak yang lurus segaris dengan pintu masuk utama bangunan gereja. Garis aksis yang terbentuk lebih diperkuat keberadaannya dengan pengaturan taman dan deretan bangunan di kiri kanan ruang terbuka. Tepat di penghujung 
jalan setapak terdapat elemen estetik relief patung St. Mary of The Angel/ Bunda Maria dan malaikat Gabriele, aksis timur-barat yang berhadapan lurus dengan pintu masuk utama bangunan gereja. Jarak keduanya cukup jauh $\pm 100 \mathrm{~m}$, namun elemen teks yang ada secara keseluruhan menjelaskan adanya relasi aksis. Aksis ini kemudian menjadi bermakna ketika direlasikan dengan aksis lain yang terbentuk oleh pintu masuk utama tapak yang berasal dari Jalan Bukit Batok East Ave dan pintu masuk samping yang dibuat saling melintas sehingga terjadi relasi aksis yang saling tegak lurus/crossing.

Elemen tanda fisik lain masih dapat ditelusuri pada isi bangunan/content baik yang berada di dalam maupun di luar bangunan. Secara keseluruhan elemen-elemen tanda yang ada akan saling mengisi, memperkuat dan membentuk rantai tanda-tanda yang menjangkarkan makna, seperti yang digambarkan Ferdinant de Saussure sebagai berikut:

Tabel 1. Rantai tanda Saussure

\begin{tabular}{|c|c|}
\hline Penanda/Signifier & Petanda/Signified \\
\hline \multicolumn{2}{|c|}{ Tanda/Makna } \\
\hline
\end{tabular}

Gereja St. Mary of the Angels berlokasi di Jl. Bukit Batok East Ave 2, no. 5 Singapore, 659918, luas area15.260,8 $\mathrm{m}^{2}$, selesai dibangun tahun 2003. Bangunan ini mengikuti gaya minimalist nampak dari penampilan muka bangunan/feature yang cenderung geometrik persegi. Pengulangan elemen bidang dan garis tanpa detail yang rumit seperti cantilever lebar \pm 10 m menjorok ke depan tanpa penopang kolom di sepanjang lebar bangunan utama, pemakaian elemen kaca lebar berkusen kayu oak, berbentuk persegi tanpa dinding memberi kesan ruang dalam gereja menyatu dengan ruang luarnya.

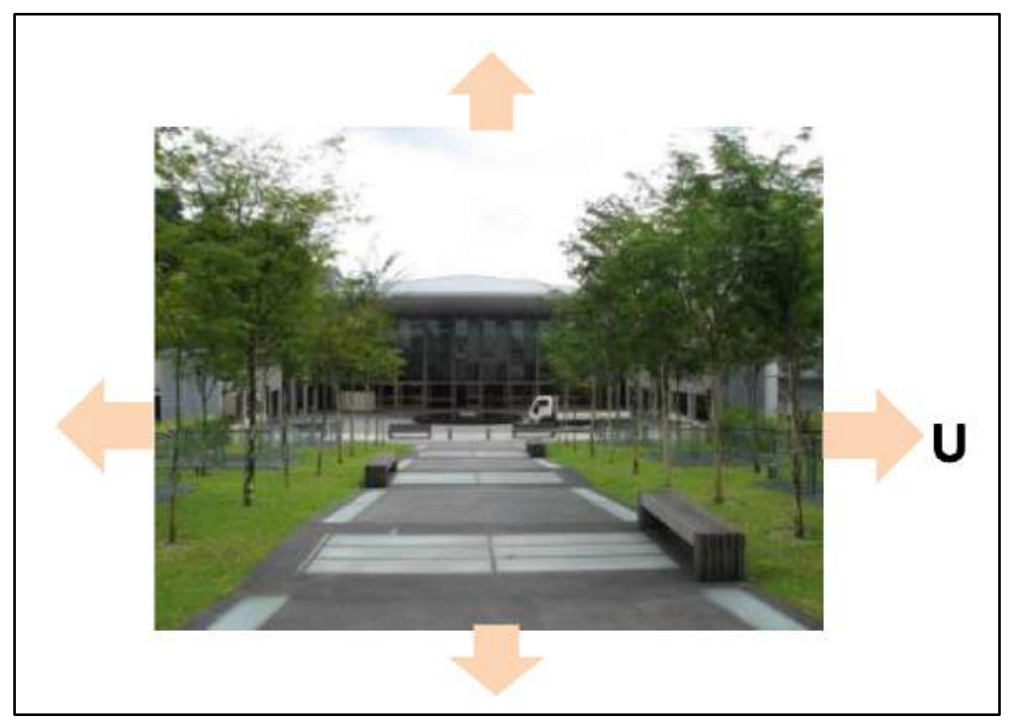




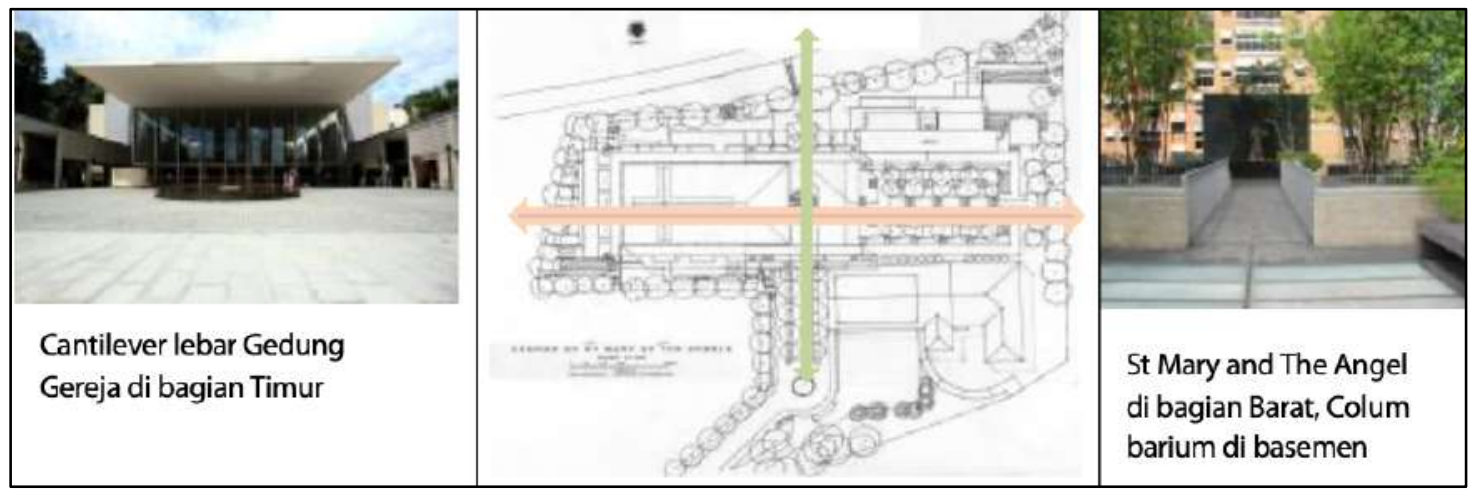

Gambar 2. Tapak Gedung Gereja St. Mary of The Angle, Aksis Timur-Barat dan Cross Sumber: Foto Dokumentasi Pribadi; http://www.St.Mary S9/content/view//20/32/

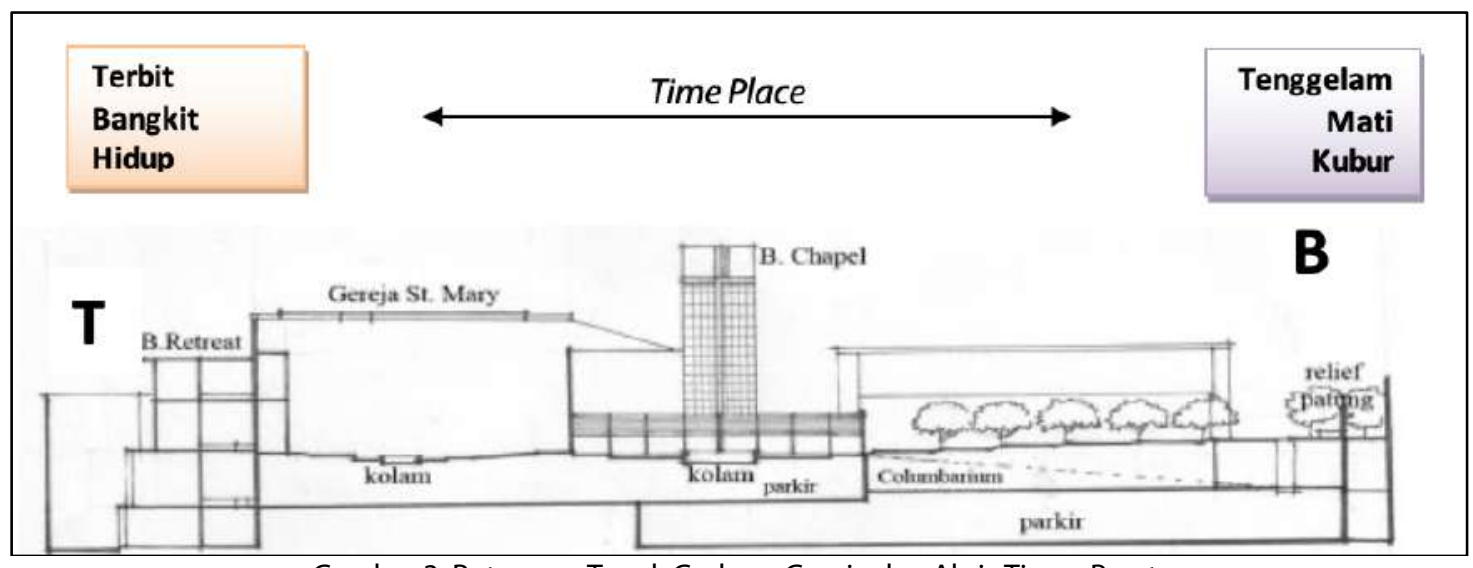

Gambar 3. Potongan Tapak Gedung Gereja dan Aksis Timur-Barat

Sumber: Dokumentasi Pribadi

Di sisi lain Gedung Gereja Injili Indonesia berlokasi di Jl. Surya Sumantri No. 44 Setrasari Plaza, Block C4. Sukagalih, Sukajadi, Bandung, Indonesia, luas $\pm 1.600 \mathrm{~m}^{2}$, tidak nampak sebagai gedung bangunan ibadah dari pintu masuknya yang berdampingan dengan pintu Giant Supermarket. Bangunan ibadah atau lebih tepatnya ruang ibadah terletak di lantai dua yang menyatu dengan supermarket di lantai pertama. Pencapaian gedung gereja tak menunjukkan tanda/ indeks menuju lokasi bangunan ibadah, cenderung tersamar karena dimensinya lebih kecil serta lokasinya yang menyatu dengan pencapaian bangunan komersial, sehingga yang tampak dikenali masyarakat adalah sebagai bangunan Giant Supermarket itu sendiri. Entrance utama gereja hanya diwakili sebuah pintu berbentuk penebalan dinding dengan kusen bergaya gotik dari kayu kamper dengan teras yang menyatu dengan teras Giant Supermarket, dilanjutkan dengan hall eskalator menuju lantai dua, tanpa elemen tanda visual yang bermakna simbolis. 


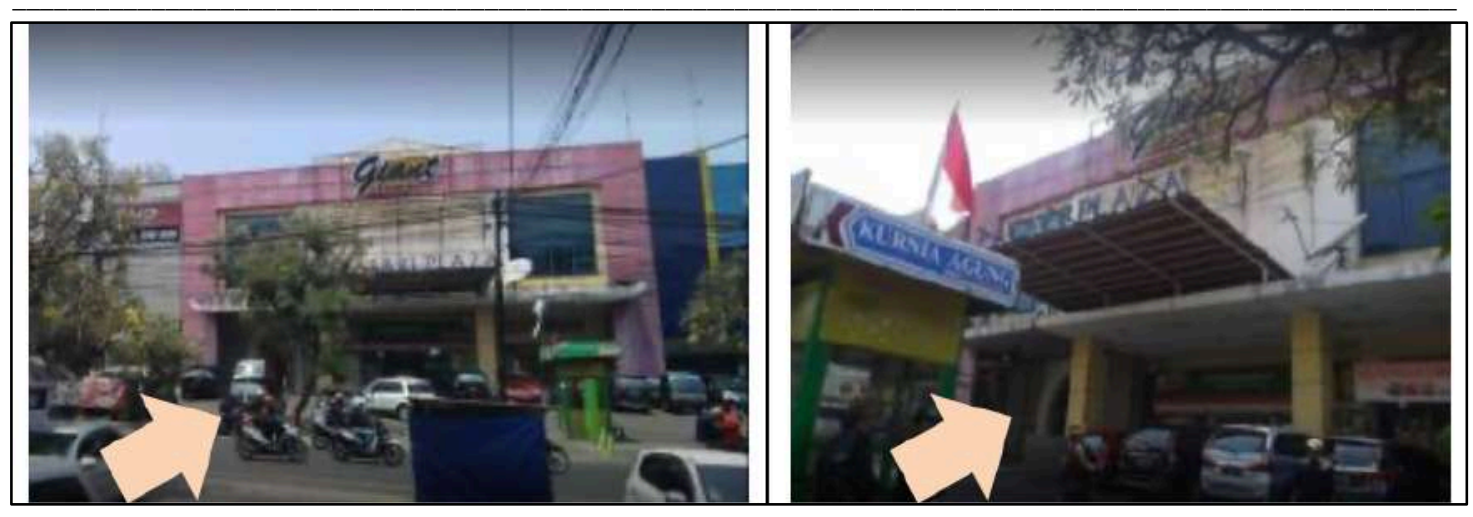

Gambar 4. Pencapaian utama tapak Gereja Injili Indonesia, di pinggir kiri,

menyatu dengan pencapaian Giant Supermarket, dengan dimensi pintu gereja yang lebih kecil dari entrance mall

Sumber: $\underline{\text { https://www.airbnb.ae/things-to-do/places/2876918 }}$

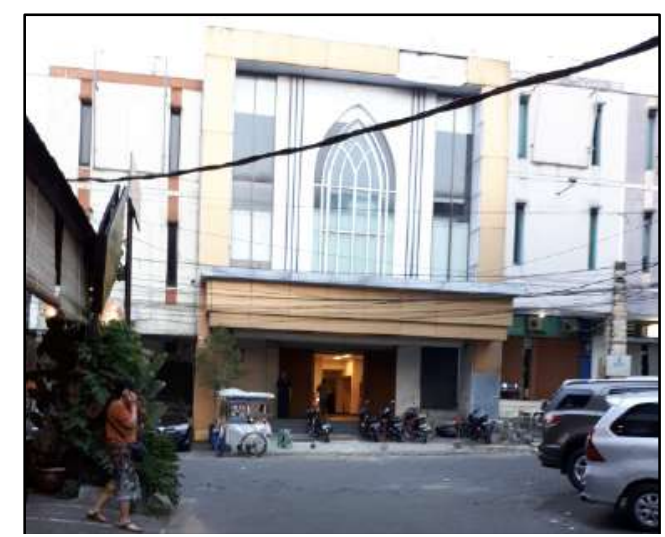

Gambar 5. Side entrance Gereja Injili Indonesia pencapaian dari dalam Setrasari Plaza Sumber: Dokumentasi Pribadi
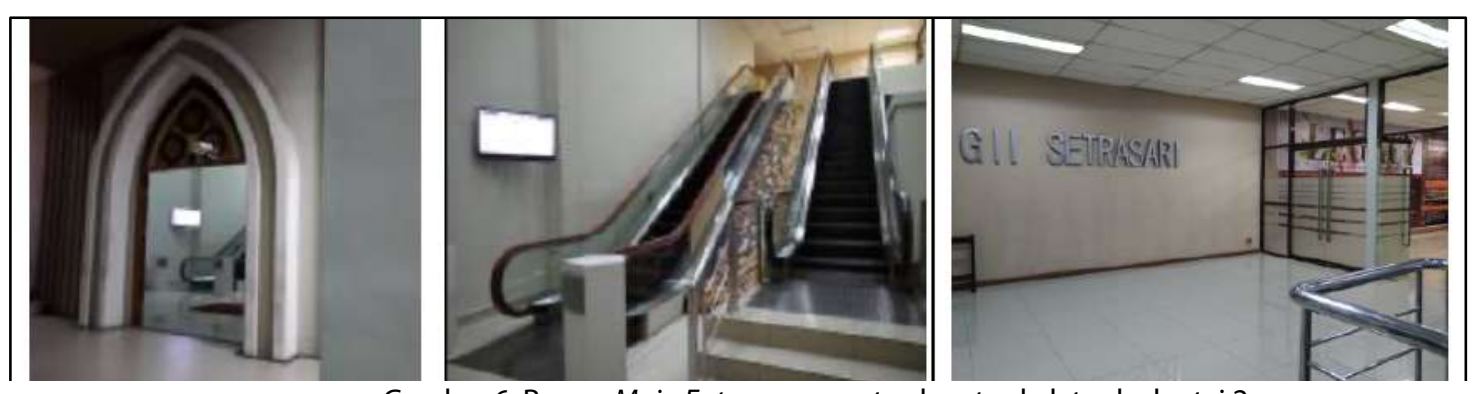

Gambar 6. Ruang Main Entrance yang terdapat eskalator ke lantai 2 Sumber: Dokumentasi Pribadi

Gambar sebelah kiri adalah pintu utama/main entrance Gereja Injili Indonesia yang letaknya di sisi pinggir kiri, berdampingan dengan entrance Giant Supermarket. Dimensi ukuran pintu entrance gereja jauh lebih kecil \pm 1:4 terhadap pintu masuk mall, dengan demikian kehadiran Gll terasa kecil, kurang mengundang dan mengalami distrupsi yaitu keterasingan dari fungsi utamanya. Bangunan ibadah yang seharusnya menjadi pusat dan sakral menjadi terasing dan tersisih karena menyatu dengan bangunan komersial yang terbuka luas. Namun demikian walau dimensinya kecil, sebagian besar jemaat gereja lebih memilih masuk melalui 
entrance utama yang berdampingan dengan entrance Giant Supermarket ini karena langsung masuk dari jalan utama Surya Sumantri daripada melalui jalan samping kompleks Setrasari Plaza (Gambar 5).

Pada entrance utama hanya disediakan hall kecil untuk naik ke lantai dua yang terdapat hall kegiatan bersama berupa lorong dengan dinding berisikan informasi kegiatan, ruang-ruang kelas Sekolah Minggu, ruang latihan koor/musik yang dapat digunakan sebagai ruang multifungsi letaknya di sebelah kiri lorong. Sementara di sebelah kanan lorong terdapat ruang makan yang sifatnya juga multifungsi, ruang pantry, ruang belajar, ruang pastori, ruang kasir, ruang administrasi, toilet, ruang perpustakaan, ruang pengumuman, dan ruang display yang representatif dengan informasi dan ilustrasi kegiatan ibadah. Di bagian ujung lorong ke arah kiri terdapat pintu masuk ke ruang ibadah dari arah belakang dengan mimbar di bagian depan.

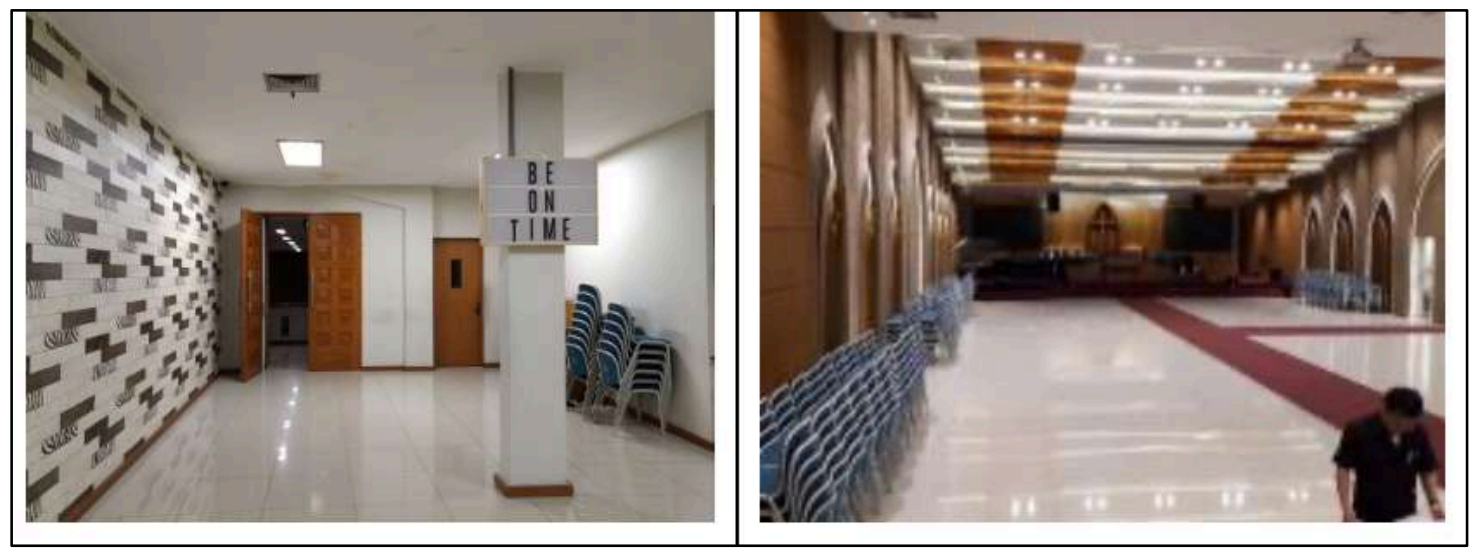

Gambar 7. Pintu masuk arah belakang dan ruang ibadah dengan suasuana usai kebaktian sore Sumber: Dokumentasi Pribadi

Keseluruhan ruang pendukung kegiatan gereja dan ruang ibadah utama terletak di lantai 2 sementara di lantai 1 adalah ruang komersial Giant Supermarket. Dalam hal ini elemen penanda yang terbaca pada tapak lebih kuat menunjuk pada bangunan komersial daripada bangunan ibadah. Tidak dijumpainya penanda yang spesifik pada elemen isi bangunan yang menunjuk pada kekhasan bangunan gereja kecuali penanda salib di belakang mimbar dengan bingkai kayu bergaya gotik. Bentuk pintu gotik ini dihadirkan repetitif menjadi elemen dekoratif dinding interior auditorium gereja. Salib adalah simbol iman kristiani yang hakiki dan menjadi tanda yang sentral pada semua bangunan gereja.

\section{METODE PENELITIAN}

Pada tahap kajian penelitian, metode yang digunakan adalah metode kualitatif komparatif 
yaitu dengan cara membandingkan elemen-elemen tanda fisik yang ada pada kedua bangunan gereja. Tanda fisik itu dapat ditelusuri dari sejak pencapaian tapak, tata letak bangunan, kehadiran dan ketidakhadiran elemen isi/content bangunan eksterior maupun interior hingga pada bentuk detail. Pemaknaan tanda fisik dilakukan melalui metode semiotika statis (Saussure,1966) hingga pemaknaan tanda kode atasikon, indeks, simbol (Bartes,1977) dan pemaknaan tanda maya/ nonfisik dilakukan melalui wawancara mendalam/in depth interview. Metode in depth interview merupakan metode etnografi modern yang dilakukan kepada jemaat gereja yang memaknai pengalamannya tidak melalui tanda fisik yang nyata, namun melalui tanda berdimensi nonfisik, ruang yang tidak nyata di dalam ide, abstrak namun dapat dirasakan keberadaannya sebagai ruang ketiga (Soja, 1999:67). Tanda yang ada tidak berkorelasi langsung melalui bahasa visual namun dapat dimaknai melalui bahasa lain seperti bahasa literal maupun bahasa audial seperti intensitas penyampaian kotbah, penulisan firman pada dinding-dinding lorong ruang gereja, paduan suara, pujian jemaat, pujian singer, kebaktian doa dan seminar kebangunan rohani. Pemaknaan tanda berdimensi nonfisik ini dapat diterima jemaat gereja dan memberi nilai pertumbuhan spiritualitas yang dapat ditangkap melalui in depth interview, padatnya kehadiran jemaat, semangat, dan kekhidmatan penyembahan jemaat dalam melaksanakan masing-masing kegiatan ibadah.

\section{PEMBAHASAN}

\section{Analisis pencapaian lokasi dan bangunan gereja}

a. Pencapaian lokasi bangunan St. Mary of the Angel dari arah selatan yaitu Jalan Bukit Batok Ave. Sebuah kawasan yang dibangun khusus untuk gereja di lantai 1 dan ruang penyimpanan abu/ bagi jemaat yang meninggal di lantai basemen. Penataan bangunan dengan penunjangnya membentuk aksis salib/Cross Timur-Barat dan aksis site entrance dari selatan dan bangunan kapel di utara sebagai titik tangkap side entrance menjadi aksis selatan-utara. Aksis salib telah diciptakan arsitek Wong Mun Summ dan Richard Hassell sebagai tanda bermakna salib. Tanda salib menjadi begitu penting dan terusmenerus dihadirkan dan diperkuat oleh elemen penunjang lain dari pengorganisasian ruang dan bangunan hingga ke detail.

b. Pencapaian lokasi Gereja Injili Indonesia dari arah utara yaitu Jalan Surya Sumantri. Sebuah kompleks bangunan komersial daerah Bandung Barat yaitu Setrasari Plaza, Gereja Injili Indonesia berada pada bagian depan Kompleks Setrasari Plaza sejajar dengan Jalan Surya Sumantri. Keberadaannya tidak nampak sebagai sebuah bangunan 
gereja, karena letaknya di lantai dua dari Giant Supermarket sejak berdiri tahun 20082019. Lokasi GII Setrasari tidak memiliki tanda fisik simbolis layaknya tanda yang dipahami bangunan gereja pada umumnya, sebaliknya tanda fisik nampak kurang relevan, dan cenderung disrupsi.

\section{Analisis pintu masuk}

a. Detail handel pintu dan gerak pintu pivot gereja St. Mary of the Angel didesain sebagai repetisi dari stilasi salib dan memaknakan salib.

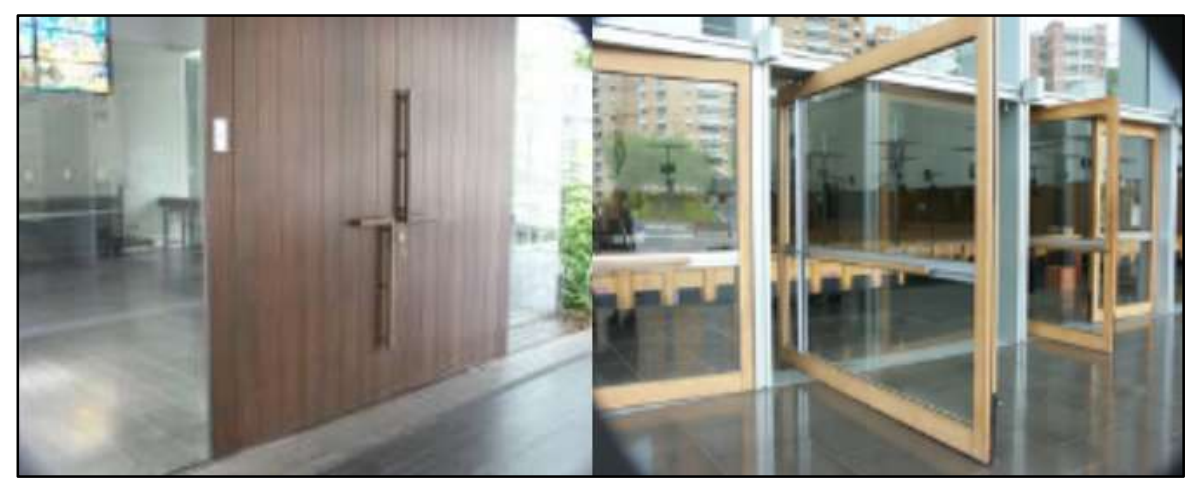

Gambar 8. Detail pegangan pintu dan gerak pintu pivot stilasi dari bentuk salib Sumber: Dokumentasi Pribadi

b. Entrance utama GII Setrasari hanya diwakili sebuah pintu besar berkesan gotik, letaknya di pinggir kiri sejajar dengan teras Giant Supermarket, dilanjutkan eskalator ke lantai 2 dan pintu masuk di lantai 2. Visual pintu yang digunakan tidak memberikan makna simbolik namun cenderung fungsional. Side entrance berada di bagian samping arah masuk dari dalam plaza, walau memiliki fasad repetisi pintu gotik di dinding lantai 2 yang menarik namun cenderung tidak terlihat. Pintu masuk samping berbentuk rolling door serupa dengan pintu masuk pertokoan yang ada di sebelahnya. Side entrance lebih berfungsi sebagai service entrance dengan ruang-ruang service di dalamnya.

\section{Analisis pelingkup ruang luar}

a. Bagian timur Gereja St. Mary of the Angel

Pelingkup ruang luar gereja St. Mary of the Angel didesain sebagai sebuah kesatuan kegiatan keimanan dari kehidupan manusia di dunia hingga kematiannya bahkan hingga kebangkitan setelah kematiannya seperti halnya Kristus yang hidup, mati, dan bangkit. Keimanan ini dihadirkan dalam fasilitas bangunan antara lain: bangunan gereja, teras besar, kolam, bangunan retret, bangunan kapel. Di depan gereja terdapat teras luas disebut entry court, yang dilindungi cantilever lebar sejauh \pm 10 meter sebagai atap teras entrance gereja. 
Ruang ini bersifat semi terbuka sekaligus semi publik. Entry court merupakan senter dari kompleks yang berukuran $\pm 40 \times 40$ m dengan kapasitas umat \pm 5000 orang. Di bagian barat laut entry court terdapat mimbar yang permanen, ruang terbuka ini dapat digunakan untuk merayakan ritual Paskah yang membutuhkan ruang terbuka.

Di bagian tengah entry court terdapat kolam air berbentuk lingkaran, sebagai The Easter Flame Reflection Pool, tempat melakukan kontemplasi ritual Paskah. Air memiliki makna khusus dalam keimanan Kristiani sebagai simbol air kehidupan, Kristus sebagai sentral diletakkan di tengah-tengah sumbu aksis timur-barat. Gereja di ujung timur dan relief patung St. Mary and The Angel sebagai ikon dari Bunda Maria dan Malaikat Gabriele di ujung barat sebagai objek penanda, terjadinya aksis dalam bentuk jalan setapak/footpath dan ruang terbuka entry court.

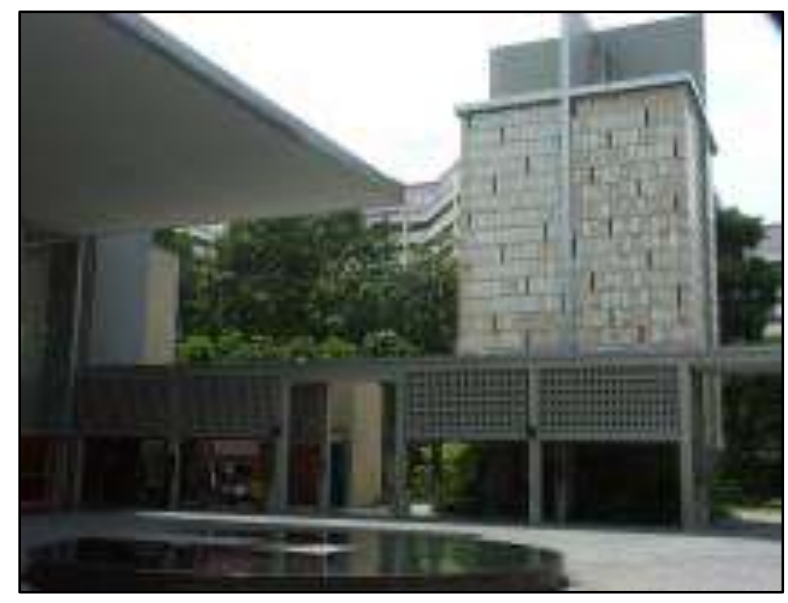

Gambar 9. Bangunan kapel dengan kolam air di pusat entry court Sumber: Dokumentasi Pribadi

b. Bagian barat Gereja St. Mary of the Angel

Fasilitas bangunan lain adalah taman kedamaian di bagian barat entry court yang disebut The Central Garden of the World Peace. Di bagian bawah/basemen dari taman itu ada ruang yang disebut columbarium, berfungsi sebagai ruang penyimpanan abu dari umat yang telah meninggal. Luasnya kurang lebih sama dengan luas entry court $\pm 1600 \mathrm{~m}^{2}$ (perhitungan dalam perkiraan, dengan melihat skala perbandingan gambar).

Di titik pertemuan kedua aksis itulah diletakkan kolam air sebagai pusat/center yang adalah simbol Kristus sendiri sebagai air kehidupan dalam skala ruang luar/ publik. Menurut iman kepercayaan Kristen di salib itulah Kristus telah menjadi pusat, mati untuk tujuan kehidupan bagi umat manusia. Simbol salib dan air kehidupan ini akan menjadi elemen repetitif yang 
akan terus dihadirkan pada elemen-elemen arsitektur Gereja St. Mary of the Angel yang lain, menjadi simbol ideologi yang mendominasi.

Perletakan Gereja St. Mary of the Angel di bagian timur kompleks memiliki perbandingan luas yang sama dengan entry court. Entry court sebagai ruang pusat/center dan Garden of the Peace sebagai atap dari columbarium yang terletak di bagian barat, telah menjadi tanda semiotika ruang/proxemics yang sarat dengan makna. Proxemics adalah kajian tentang struktur ruang yang merupakan struktur jarak serta pengorganisasian ruang di dalam berbagai bentuk kehidupan sehari-hari. Elemen dari proxemics terdiri dari 3 hal (Barthes,1977:50) yaitu ruang/space/distance, waktu/time, objek/fisik. Pengorganisasian dari ketiga elemen proxemics tersebut memiliki kapasitas membentuk tanda yang menghasilkan makna/meaning tertentu, bagaimana manusia berkomunikasi dengan objek fisik di dalam ruang dan waktu berdasarkan kode tertentu, serta mampu menghasilkan suatu makna.

Menurut Newton, ruang dan waktu membentuk wadah bagi peristiwa/event, yang sama nyatanya dengan objek yang ada di dalamnya dan selanjutnya Albert Einstein menemukan pemahaman bahwa realitas gerak dari ruang dan waktu tersebut dapat digabungkan secara matematis ke dalam satu objek simetris menjadi ruang-waktu/time-place. Pengorganisasi pelingkup ruang luar kompleks Gereja St. Mary of the Angel menunjuk pada metaphora dari orientasi matahari. Matahari terbit di ufuk timur di situlah dirancang dan diletakkan bangunan gereja sementara matahari tenggelam di barat di situlah diletakkan bangunan columbarium, di lantai basemen dari The Central Garden of The World Peace indeks dari penguburan, letaknya ada di dalam tanah. Kubur yang sunyi simbol dari kematian di bagian bawah dilingkupi oleh taman kedamaian yang abadi di bagian atas untuk menguburkan kematian.

Satu di antara hakikat gereja adalah mewartakan kabar bahagia tentang kedatangan Kerajaan Allah yang dijanjikan dan mewahyukan rahasia keselamatanNya lewat ketaatan Kristus melaksanakan penebusan kepada manusia. Setara dengan metafora matahari terbit di timur, pecahnya hari yang baru, terbitnya kabar bahagia, terbitnya cahaya matahari adalah simbol dari terang bagi dunia yaitu keselamatan dari kematian yang kekal. Dan abu dari jasad manusia sebagai simbol kematian, tersimpan dalam columbarium merupakan refleksi dari metafora matahari yang tenggelam, terkubur di barat, letaknya di basemen karena indeks dari kubur/tanah. Keduanya direlasikan oleh suatu aksis yang memaknakan ideologi: hidup kemudian mati namun akan bangkit/hidup kembali di timur melalui Kristus yang tersalib, 
tubuh Kristus yang tersalib, tergantung namun melayang menyimbolkan kematianNya sekaligus kebangkitanNya dan kebangkitan bagi mereka yang mati dalam iman kepada Kristus yang bangkit.

c. Pelingkup luar Gereja Injili Setrasari berada dalam Kompleks Mall Setrasari Plaza, berdampingan dengan berbagai bangunan umum seperti pertokoan, mall, kantor perdagangan, kantor pos, kantor pelayanan jasa, restoran, salon, dan lain-lain. Keberadaannya sebagai bangunan ibadah di tengah-tengah bangunan umum lain tidak relevan dalam tipologi bangunan, tidak relevan pula dalam memberikan tanda berdimensi fisik. Keberadaan gereja yang bermakna sakral seakan terasing dari makna fisik, terdisrupsi namun di sisi lain makna sakralitasnya tampil melalui dimensi yang berbeda.

\section{Analisis Isi /Content bangunan}

a. Elemen ruang yang paling utama pada bangunan Gereja St. Mary of the Angel adalah Panti Imam yang terdapat podium, altar dan kolam pembaptisan Panti Imam adalah tempat dilakukan perayaan liturgi, menjadi pusat orientasi, dan menjadi hal utama yang menentukan konfigurasi ruang dalam bangunan gereja.

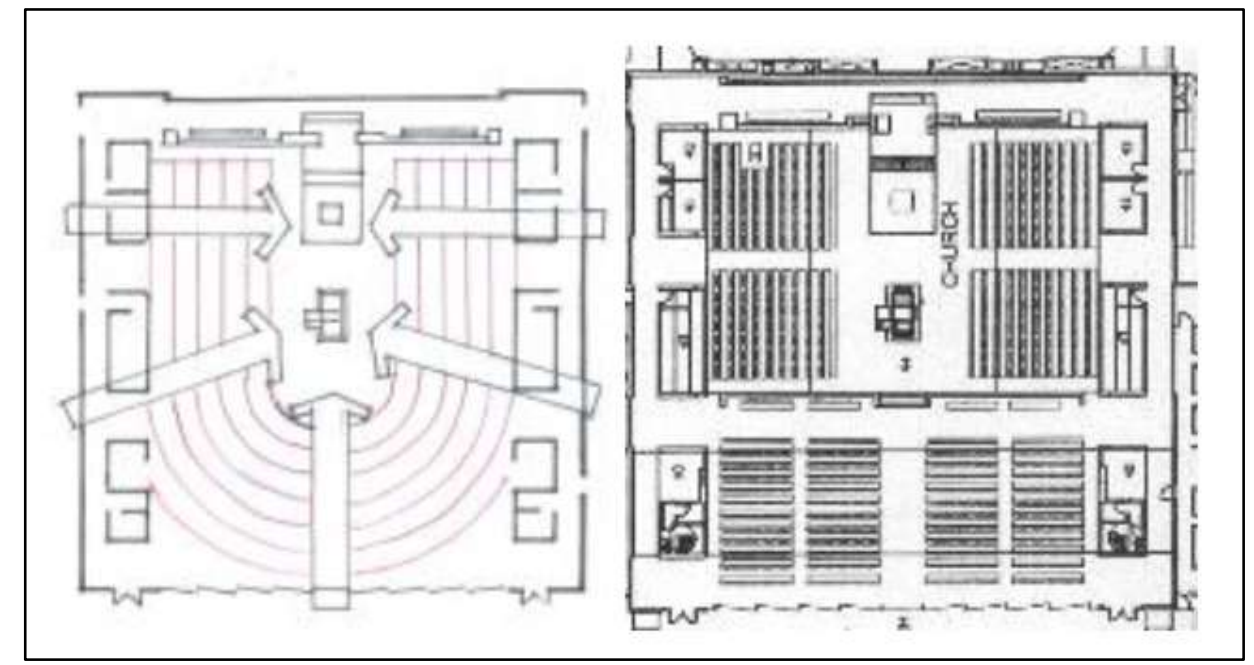

Gambar 10. Denah Panti Imam dengan strukturnya yang memusat ke kolam air Sumber: Dokumentasi Pribadi 


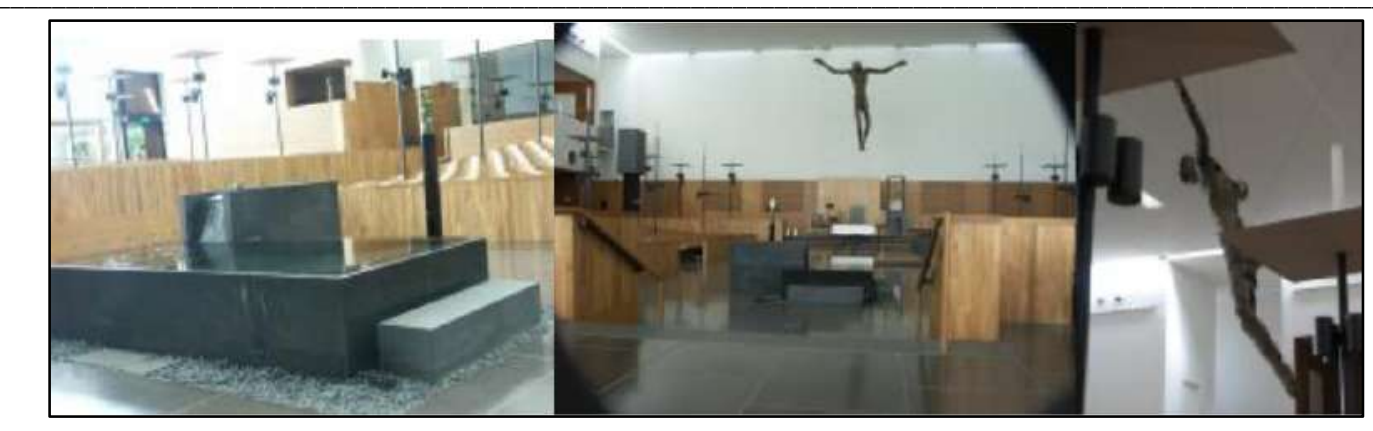

Gambar 11. Kolam yang selalu terisi penuh air dengan Patung Yesus Melayang di atas mimbar Sumber: Dokumentasi Pribadi

Kolam air yang diletakkan di tengah-tengah digunakan pada acara ritual sakramen baptis yaitu suatu acara liturgi gerejawi ketika melakukan pembaptisan terhadap umat. Kolam dibuat permanen sebagai repetisi simbol air kehidupan yang ada di entry court, diupayakan hadir juga di dalam ritual gereja, hadir di tengah-tengah umat dan diharapkan juga hadir di dalam diri personal umat, sebagai value yang diinginkan desainer. Kehadiran kolam dan air di center gereja sebagai elemen fisik menjadi konsep desain yang belum pernah dijumpai pada desain gereja-geraja di Indonesia.

Ada bagian yang lebih tinggi dari kolam, bagian ini mengaliri kolam secara konstan sedemikian rupa sehingga permukaan kolam senantiasa dalam keadaan penuh, tepat rata dengan bibir kolam. Mengkonotasikan simbol kehidupan umat yang harus terus diisi dengan air kehidupan yaitu Kristus sendiri sampai menjadi penuh, memperoleh makna kehidupan yang seutuhnya secara terus menerus/continous fulfil. Kehidupan yang mengasihi sesama manusia tidak mungkin dilakukan sepenuhnya tanpa diri kita sendiri terus-menerus diisi oleh air kehidupan dari Sang Sumber Hidup.

Patung Kristus yang disalibkan merupakan icon Kristus saat melewati penderitaannya, melaksanakan penebusan bagi umat manusia. Patung tidak diletakkan pada rangka salib kemudian diletakkan pada dinding selayaknya dijumpai dalam interior gereja di Indonesia, namun digantung dengan menggunakan tali baja sehingga nampak melayang tinggi di atas podium. Patung dikonstruksikan melayang sebagai metafora matahari yang sedang terbit, memaknakan kebangkitan dan kehidupan baru. Setara dengan konsep ruang luar kompleks ketika mengatur massa bangunan/ objek, ruang antar massa/ distance yang ditunjukkan oleh aksis dan waktu. Patung dikonstruksikan tergantung melayang dengan posisi menjulang tinggi di atas kepala dan berhadapan dengan umat, sosok yang diagungkan itu diangkat ke atas memaknakan Vertically Divinity (makna value menurut teori Barthes) karena pengorbananNya demi keselamatan umat manusia. 


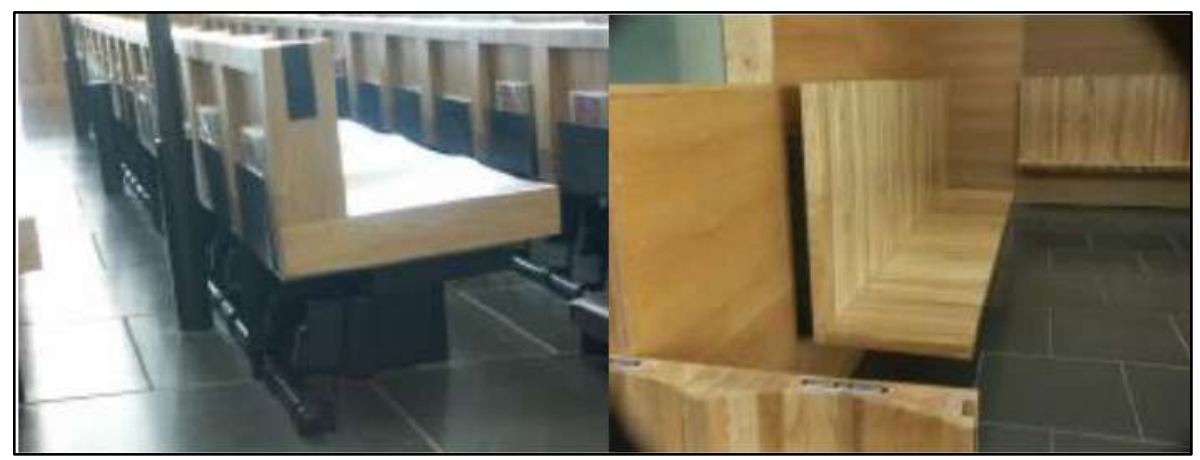

Gambar 12. Detail kursi di auditotium gereja seperti stilasi dari salib Sumber: Dokumentasi Pribadi

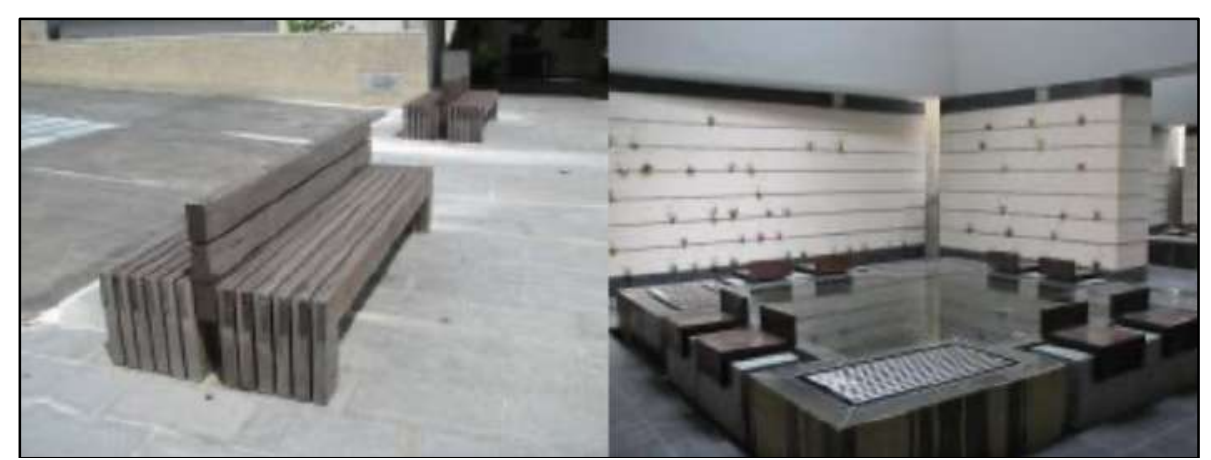

Gambar 13. Detail kursi di central garden, di ruang gereja, di columbarium keseluruhannya adalah stilasi dari salib. Sumber: Dokumentasi Pribadi

Bentuk kursi dibuat dengan melakukan stilasi terhadap bentuk salib/cross untuk mengharmonikan bentuk dan makna sakralnya.

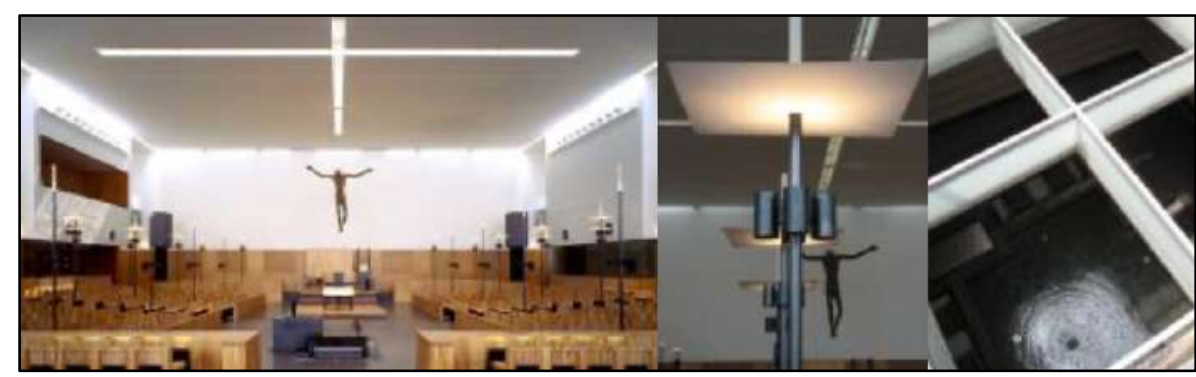

Gambar 14. Detail skylight, lampu duduk ruang gereja dan skylight di columbarium keseluruhannya adalah stilasi dari salib Sumber: Dokumentasi Pribadi

b. Elemen ruang yang paling utama pada bangunan Gereja Injili Indonesia adalah ruang mimbar dengan auditoriumnya, tanda visual yang paling kuat adalah salib yang terletak di belakang mimbar, simbol penebusan dan keselamatan yang dikerjakan Kristus untuk umat manusia. 


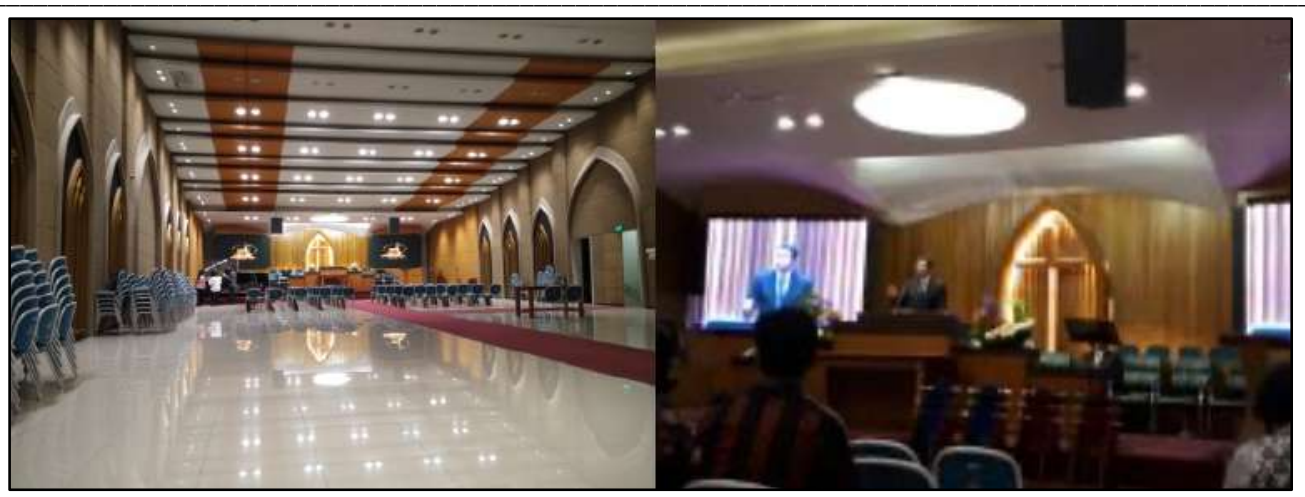

Gambar 15. Ruang auditorium gereja dan mimbar Sumber: Dokumentasi Pribadi

Ruang auditorium didesain tidak permanen, susunan kursi bisa diubah-ubah sesuai kegiatan dan jumlah jemaat yang hadir. Kebaktian hari Minggu dilakukan 3 kali, 2 kali di waktu pagi hingga siang hari dengan jumlah jemaat 600-800 orang, 1 kali di waktu sore hari dengan jumlah jemaat 200-300 orang. Penggunaan kursi jenis Chitose dipilih untuk tujuan dapat dilipat, mudah dan ringan untuk dibongkar pasang. Ruang auditorium gereja dapat digunakan untuk acara doa bersama di hari Selasa pagi dan Rabu malam, kegiatan katekisasi, seminar, kebaktian kebangunan rohani, ruang sharing pergumulan iman antar jemaat, ruang latihan musik dan singer di hari kerja sesuai program perencanaan kegiatan tahunan gereja.

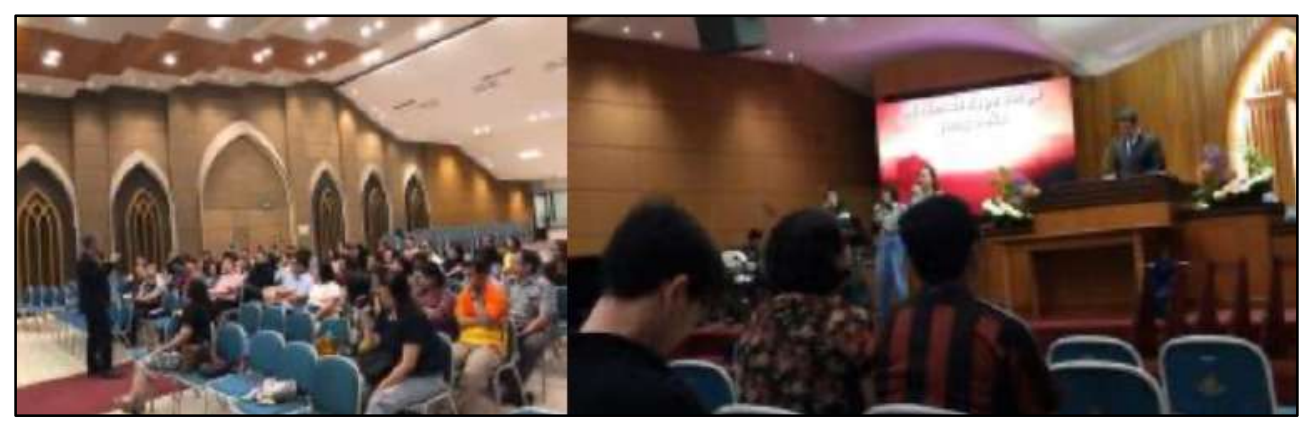

Gambar 16. Ruang auditorium gereja sebagai multifungsi, singer dan penayangan syair pada layar Sumber: Dokumentasi Pribadi

Tidak ada tanda visual yang didesain menjadi ikon, indeks atau simbol kecuali sebuah salib besar di belakang mimbar. Terdapat 2 layar lebar menghadap tempat duduk jemaat di kiri kanan mimbar ditayangkan untuk nats dan presentasi kotbah, teks lagu pujian, video klip, informasi warta gereja, talkshow dan sebagainya. Pujian jemaat dan paduan suara diiringi dengan permainan alat musik seperti, drum, organ, gitar elektrik dan piano, dipandu oleh para singer secara live show dan penayangan syair lagu di layar mimbar kemudian disambut pujian penyembahan oleh seluruh jemaat. 
Komparasi Ruang Fisik Gereja St. Mary Singapore dan Ruang Maya Gereja Injili Indonesia Setrasari

Dinding dan ruang lorong menuju pintu masuk gereja digunakan menjadi tempat pengumuman kegiatan jangka pendek, display tentang sejarah, nats alkitab, pembangunan iman dan renungan. Terdapat ruang kebersamaan kegiatan jemaat yang sifatnya juga multifungsi, seperti dapat berfungsi sebagai ruang makan, ruang diskusi, ruang pemeriksaan kesehatan, ruang kegiatan bersama seperti memasak, kegiatan lomba pekan keluarga, pemutaran film, game, olahraga pingpong dan spot untuk swafoto. Ruang spot ini didesain renewal untuk memberi suasana penghayatan jemaat akan event-event khusus seperti hari Paskah, Tahun Baru Imlek, Natal, Pantekosta, Bulan Keluarga, Hari Ibu Internasional, Hari Bapak, Hari Kemerdekaan RI, dan sebagainya.

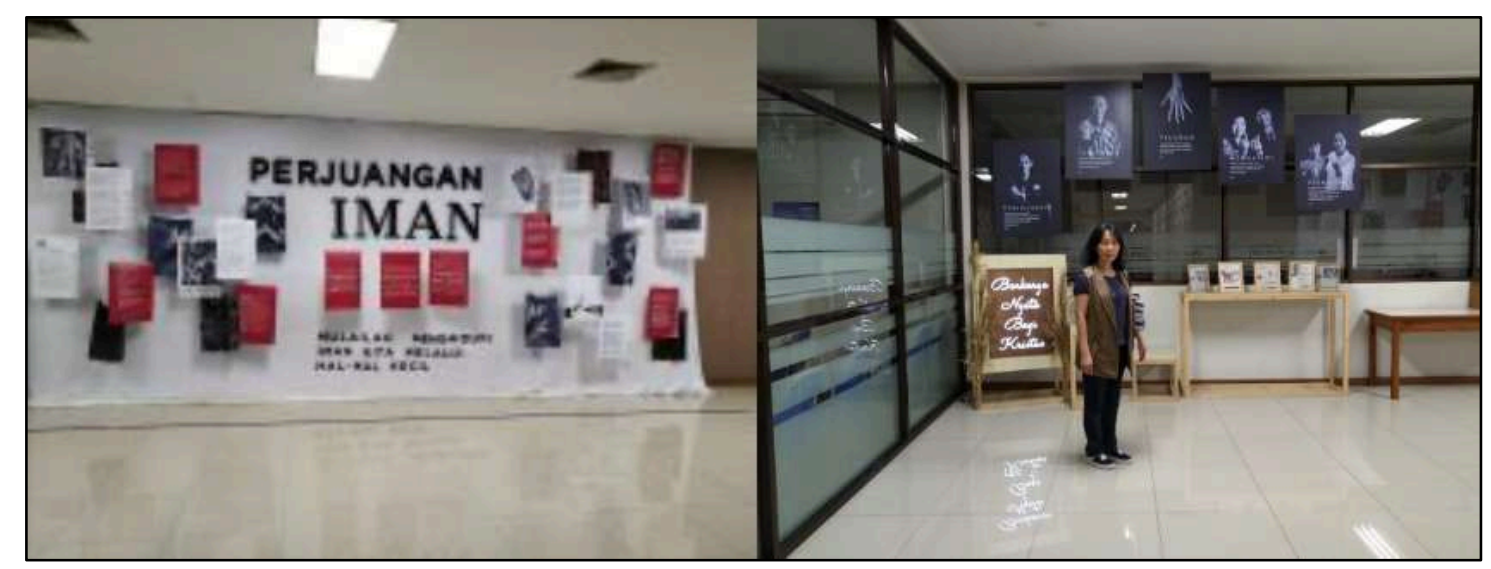

Gambar 17. Ruang display kebangunan iman, ruang renungan yang terus berubah Sumber: Dokumentasi Pribadi

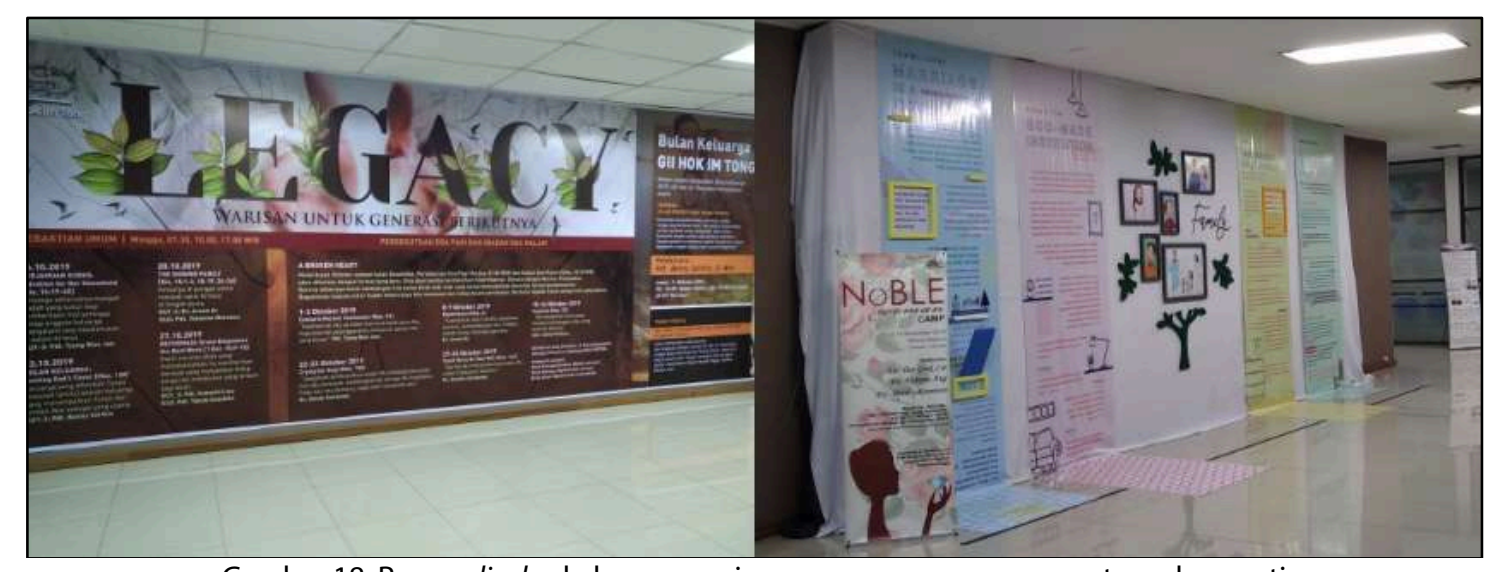

Gambar 18. Ruang display kebangunan iman, ruang renungan yang terus berganti Sumber: Dokumentasi Pribadi 


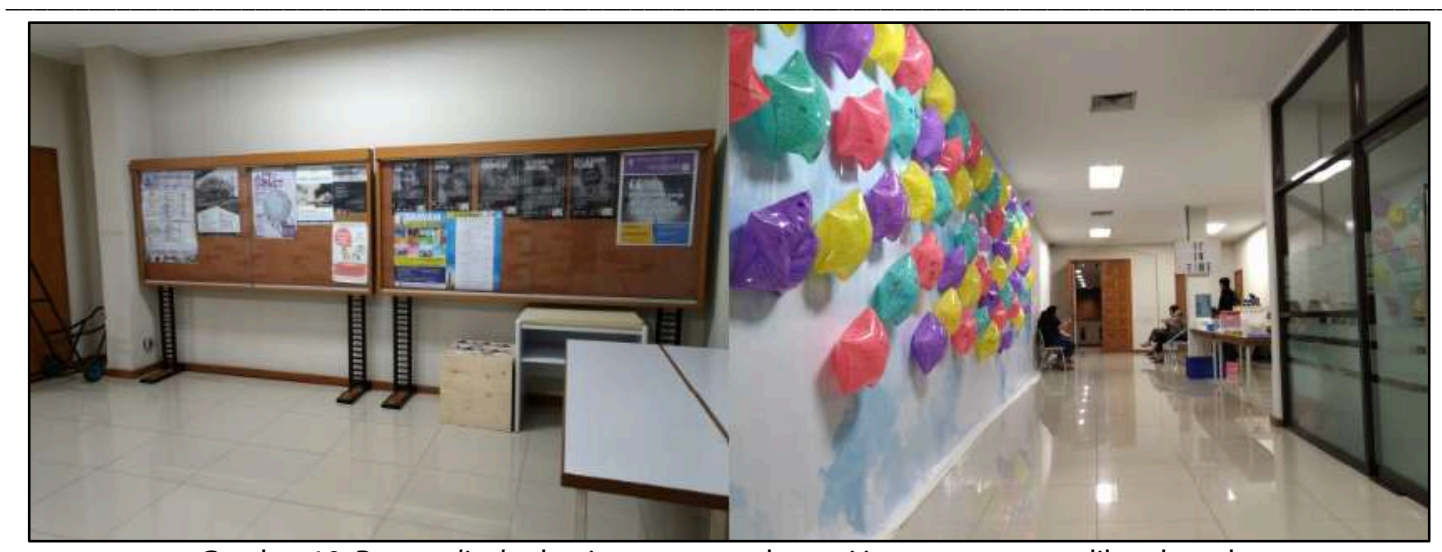

Gambar 19. Ruang display kegiatan, ruang ekspresi iman yang terus dikembangkan Sumber: Dokumentasi Pribadi

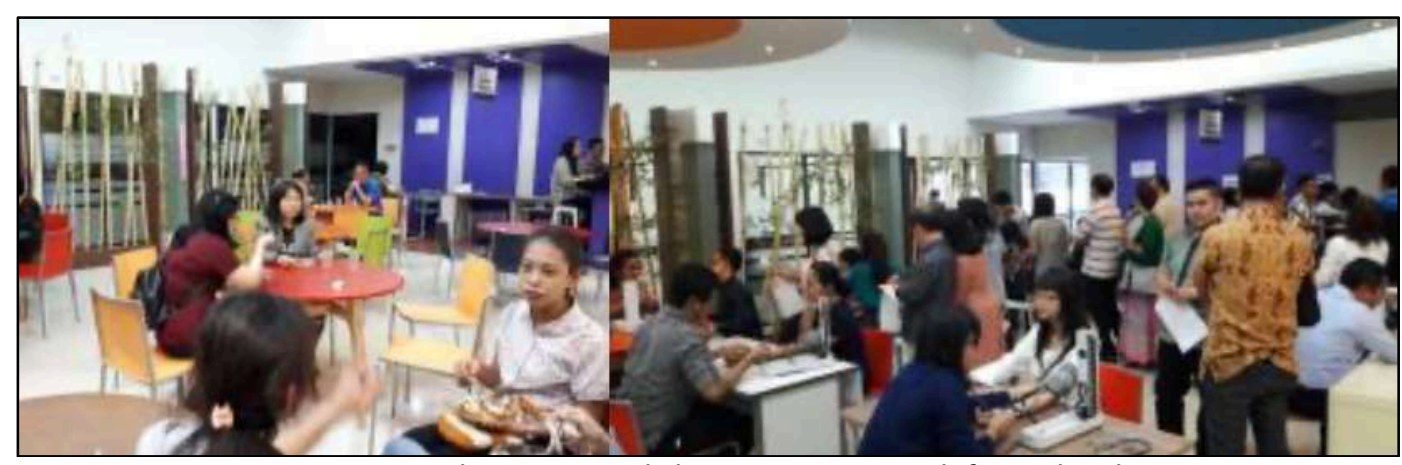

Gambar 20. Ruang kebersamaan yang multifungsi/kesehatan Sumber: Dokumentasi Pribadi

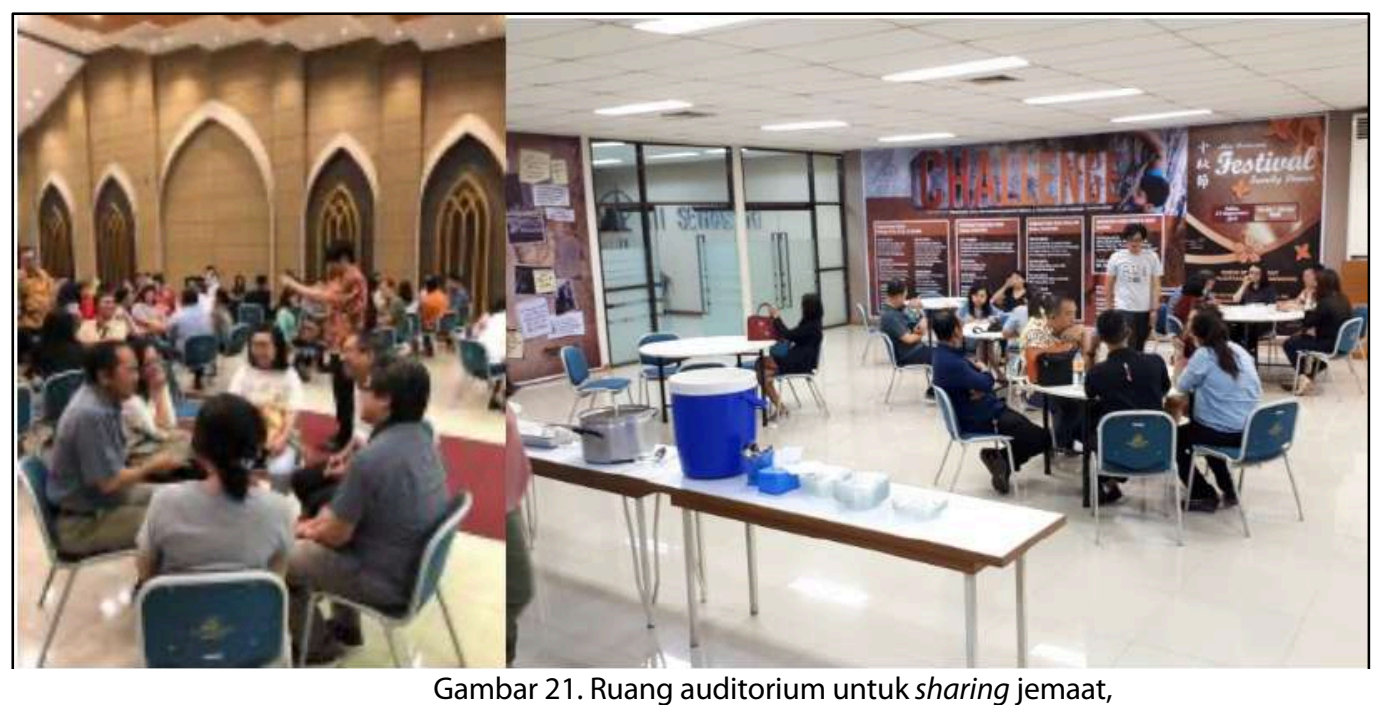

ruang dinding pengumuman sekaligus ruang kebersamaan jemaat untuk saling berbagi Sumber: Dokumentasi Pribadi

Dinding pengumuman tidak memiliki makna simbolik, hanya makna pragmatis sebagai pemisah ruangan dan lokasi pengumuman kegiatan dan display serta jalur sirkulasi menuju pintu masuk gereja, namun juga dapat terus bergeser memenuhi fungsi lain yang terus berubah sesuai program kegiatan gereja. Perbedaan fungsi ruang ini terus diciptakan tanpa ikon, indeks, atau simbol yang dijangkarkan, namun sebaliknya terus digeser dan diganti 
untuk memenuhi fungsinya yang baru dan dinamis dalam meraih visi ke depan. Mulai dari ruang yang berdimensi nyata menjadi ruang berdimensi idea, yang tak nyata mengarah pada dimensi harapan ke depan yaitu nilai-nilai ilahiah yang berpusat pada salib yaitu Kristus sendiri.

\section{PENUTUP}

Elemen-elemen simbolik yang ada pada objek arsitektur rumah ibadah Gereja St. Mary of the Angel, selain berperan membentuk suasana sakral pada bangunan ibadah, juga memberi karakter khusus yang menunjukkan hakikat, ideologi, hasrat/desire, orientasi, nilai-nilai yang berlaku pada penganut kepercayaan agama tersebut. Perwujudan arsitektur Gereja St. Mary of the Angel tidak hanya mewadahi kegiatan ritual saja melainkan juga menjadi representasi dari hakikat, ideologi, sosialitas dan nilai-nilai yang berlaku dalam kepercayaan Kristiani. Makna-makna di atas dapat dibaca dari penataan antar massa bangunan, jarak antara objekobjek, dan simbol-simbol yang digunakan mampu menciptakan dimensi ruang dan waktu yang dapat dibaca dan dimaknai. Komparasi tanda visual pada Gereja Injili Indonesia Setrasari menunjukkan nilai yang berkebalikan mulai dari tanda viual yang ada pada tapak hingga organisasi ruang yang ada cenderung tidak relevan sebagai bangunan ibadah yang representatif. Pengorganisasian ruangnya didesain lebih bersifat fungsional yang terus menerus bergeser, dari yang berdimensi fisik/ nyata bergerak menjadi berdimensi nonfisik, audial, tak nyata/maya/imagine, bahkan secara fisikal cenderung terdisrupsi. Namun demikian gereja dengan hanya satu tanda simbolik yaitu Salib di mimbar menghadap jemaat yang melaksanakan ibadah menjadi titik center yang mendorong jemaat memasuki dimensi ilahiah yaitu berpusat pada Kristus dalam segala laku hidupnya.

\section{Buku}

\section{DAFTAR PUSTAKA}

Barthes, Roland. (1977). Image, Music, Text. London: Fontana Press.

De Saussure, Ferdinand. (1966). Coursce in General Linguistics (trans: Wade Baskin, ed. Baily and A. Sechehaye). New York: McGraw-Hill.

Eco, Umberto. (1979). A Theory of Semiotic. Bloomington: Indiana University Press.

Soja, E. (1999). Thirdspace: Journeys toLos Angeles and Other Realandlmagined Places. Oxford: Basil Blackwel.

Jurnal

Adi Putra, Ghoustanjiwani. (2016). Pola Tatanan Pembentukan Ruang Ketiga Pada Ruang Public Urban, Jurnal Spectra Vol. 14, No.28

Sumber Online 
Komparasi Ruang Fisik Gereja St. Mary Singapore dan Ruang Maya Gereja Injili Indonesia Setrasari

http: //www.stmary.S9/content/view/20/S2/, diunduh 2 juli 2009 pukul 17.00

https://www.google.com/maps/uv?hl=id\&pb=!1s0x2e68e6844488a8e9\%3A0x8d3ba5845e 08e49!2m22!2m2!1i80!2i80!3m1!2i20!16m16!1b1!2m2!1 m1!1e1!2m2!1m1!1e3!2m2!1m 1!1e5!2m2!1 m1!1e4!2m2!1m1!1e6!3m1!7e115!4shttps\%3A\%2F\%2Flh5.googleusercont ent.com\%2Fp\%2FAF1QipMullm1LzpXy721cwksbs7HG-cCdnY-drwARyZi\%3Dw232h156-n-k-no!5sGiant\%20Super\%20Mall\%20di\%20Jl\%20Surya\%20Sumantri\%20\%20Penelusuran\%20Google!15sCAQ\&imagekey=!1e10!2sAF1QipO EY2AkZfac7p7XNT2_wXXVR6dd-a9Yg1QUMU, diunduh 24 September 2019 pukul 19.00 